\title{
PENINGKATAN DISPOSISI MATEMATIS DAN PRESTASI BELAJAR MATEMATIKA MELALUI PEMBELAJARAN TIPE AIR (AUDITORY, INTELLECTUALY, REPETITION)
}

\author{
Esti Kurnia, Meita Fitrianawati \\ PGSD, Universitas Ahmad Dahlan \\ E-mail: estikurnia036@gmail.com
}

\begin{abstract}
This study aims to determine the increase in mathematical disposition and mathematics learning achievement through learning AIR type (Auditory, Intelectualy, repetition). This type of research is a classroom action research (CAR), with Kemmis and Mc. Taggart which includes planning, implementation, observation and reflection. This study uses two cycles with each cycle having two meetings, so in this study there were four meetings. The research subjects are 25th grade students, and the object of research is mathematical disposition and mathematics learning achievement. Data collection techniques of the study is using observation, testing, and documentation. The results of the study indicate an increase in the first cycle from the aspect of mathematical disposition which reached $48.72 \%$ in the first cycle increased to $61.815 \%$ in the second cycle. The average class in the first cycle was $69.04 \%$ to $87.68 \%$ in the second cycle. And classical completeness reached $68 \%$ in the first cycle increased to $84 \%$ in the second cycle. So it can be said that research during cycle I and cycle II showed an increase in students' mathematical disposition and mathematics learning achievement with AIR type cooperative learning.
\end{abstract}

Keywords: AIR model, mathematical disposition and learning achievement

\begin{abstract}
Abstrak
Penelitian ini bertujuan untuk mengetahui peningkatan disposisi matematis dan prestasi belajar matematika melalui pembelajaran tipe AIR (Auditory, Intelectualy, repetition). Jenis penelitian ini adalah penelitian tindakan kelas (PTK), dengan desain penelitian Kemmis dan Mc. Taggart yang meliputi perencanaan, pelaksanaan, pengamatan dan refleksi. Penelitian ini menggunakan dua siklus dengan setiap siklus ada dua kali pertemuan, sehingga dalam penelitian ini ada empat kali pertemuan. Subjek penelitian yaitu siswa kelas III yang berjumlah 25 siswa, dan objek penelitian yaitu disposisi matematis dan prestasi belajar matematika. Teknik pengumpulan data data menggunakan metode observasi, tes, dan dokumentasi. Hasil penelitian ini menunjukkan peningkatan pada siklus I dari aspek disposisi matematis yang mencapai $48,72 \%$ pada siklus I meningkat menjadi $61,815 \%$ pada siklus II. Rata-rata kelas pada siklus I yang semula $69,04 \%$ menjadi $87,68 \%$ pada siklus II. Serta ketuntasan klasikal mencapai $68 \%$ pada siklus I meningkat menjadi $84 \%$ pada siklus II. Sehingga dapat dikatakan bahwa penelitian selama siklus I dan siklus II menunjukkan adanya peningkatan disposisi matematis siswa dan prestasi belajar matematika dengan pembelajaran kooperatif tipe AIR.
\end{abstract}

Kata kunci: model AIR, disposisi matematis dan prestasi belajar 


\section{PENDAHULUAN}

Pendidikan sangat berperan penting bagi pengembangan siswa agar kelak menjadi sumber daya manusia berkualitas. Pendidikan adalah sarana dan alat yang tepat dalam membentuk masyarakat dan bangsa yang dicita-citakan, yaitu masyarakat yang berbudaya dan dapat menyelesaikan masalah kehidupan yang dihadapinya. Salah satu pendidikan yang dapat dilakukan adalah pendidikan di sekolah mulai dari pendidikan dasar, pendidikan menengah hingga pendidikan tinggi dengan segala aspeknya kurikulum, metode, pendekatan, strategi dan model yang sesuai, fasilitas yang memadai dan sumber daya manusia yang profesional adalah aspek yang saling berkaitan untuk mencapai tujuan yang direncanakan.

Pembelajaran matematika merupakan suatu proses yang kompleks, karena dalam kegiatan pembelajaran senantiasa mengintegrasikan berbagai komponen dan kegiatan, yaitu siswa dengan lingkungan belajar untuk diperolehnya perubahan perilaku sesuai dengan tujuan (kompetensi) yang diharapkan. Oleh karena itulah pembelajaran dapat disederhanakan menjadi suatu resep untuk membantu siswa belajar Matematika.

Menyadari akan pentingnya matematika dalam kehidupan sehari-hari, maka pembelajaran matematika yang diberikan guru merupakan hal yang penting untuk diperhatikan, pemilihan metode pembelajaran matematika yang tepat akan membuat matematika disukai oleh siswa. Namun kenyataannya, matematika masih dianggap sebagai suatu pelajaran yang sulit, bersifat abstrak dan bahkan pelajaran yang menakutkan bagi sebagian siswa. Sifat abstrak ini menyebabkan banyak siswa mengalami kesulitan dalam matematika Sormin dkk (2017: 2).

Adapun faktor lain yang menentukan keberhasilan matematika yaitu disposisi matematis. Disposisi matematis tersebut sebenarnya telah tercantum dalam tujuan pembelajaran matematika, yaitu memiliki sikap menghargai kegunaan matematika dalam kehidupan, rasa ingin tahu, perhatian dan minat dalam mempelajari matematika, serta sikap ulet dan percaya diri dalam pemecahan masalah. Hasil penelitian dari Retnowati dkk (2013: 3) yang dilakukan kebanyakan siswa yang beranggapan bahwa matematika merupakan suatu pelajaran yang sulit untuk dikuasai dan kurang diminati banyak siswa. Anggapan tersebut muncul karena kebanyakan siswa tidak mampu mengerjakan soal matematika, kurang gigih dalam mengerjakan, dan kurangnya keingin tahuan serta rasa percaya diri dalam mengerjakan soal matematika. Kondisi tersebut jika tidak segera diatasi akan mengakibatkan rendahnya disposisi matematis siswa. Sikap-sikap siswa yang dapat menumbuhkan disposisi matematis adalah senang belajar matematika, semangat untuk belajar matematika, gigih dalam mengerjakan soal matematika serta percaya diri dalam menjawab soal matematika. Dengan begitu disposisi matematika akan meningkat dan prestasi belajar siswa juga akan lebih meningkat.

Hasil TIMSS (dalam Djuanda dkk, 2015: 3) menunjukan bahwa kemampuan matematis siswa di Indonesia masih rendah. Peningkatan skor matematika yang diperoleh berada pada peringkat 44 dari 49 negara dengan skor yang diperoleh adalah 397. Pada kenyataan hasl penelitian yang dilakukan Sukamto (dalam Djunda dkk, 2013: 3) terhadap siswa kelas V SD N Sekaran 1 Semarang menunjukan bahwa disposisi matematis siswa sebesar 61,9 \% berada pada kategori rendah. Siswa dapat mengembangkan disposisi matematisnya pada saat mempelajari aspek kemampuan matematisnya. Siswa dapat hilang rasa percaya dirinya apabila siswa tersebut gagal dalam memecahkan masalah. Hal ini menyebakan siswa menjadi kurang aktif dalam proses pembelajaran, tidak berani untuk bertanya pada guru, serta memilih untuk diam. Pada akhirnya siswa mudah cepat putus asa dan beranggapan bahwa matematika suatu pembelajaran yang sangat sulit. Sehingga menyebabkan rendahnya disposisi matematis di Indonesia. 
Berdasarkan pendapat diatas pentingnya disposisi matematis siswa dalam tujuan untuk memahami konsep dasar matematika, bukan dengan hafalan saja namun harus dengan penguasaan dan pemahaman materi serta rumus-rumus yang ada dalam matematika, diharapkan siswa mampu menerapakan rumus matematika dengan baik dan benar, serta memiliki sikap positif (disposisi) terhadap kegunaan matematika dalam kehidupan seharihari, yaitu rasa ingin tahu, perhatian dan minat mempelajari matematika, serta sikap ulet dan percaya diri dalam pemecahan masalah. Upaya guru menciptakan kondisi pembelajaran yang menyenangkan dengan berbagai model pembelajaran yang tepat bagi siswa dapat mengembangkan disposisi matematis siswa. Semakin tinggi disposisi matematis siswa maka tingkat percaya diri siswa dalam menguasai dan mengerjakan soal matematika, maka prestasi siswa akan meningkat.

Berdasarkan hasil wawancara pada tanggal 22 Oktober 2018 sampai tanggal 25 Oktober 2018 dengan guru kelas 3 SD Negeri Awu-Awu menyebutkan bahwa banyak siswa yang jarang mengajukan pertanyaan pada guru sehingga guru aktif sendiri dalam menjelaskan apa yang telah disiapkannya sehingga, membuat siswa cenderung pasif dalam pembelajaran. Hal ini menyebabkan tingkat percaya dalam pembelajaran matematika masih kurang, kurang gigih dalam mencari solusi penyelesaian soal matematika, keingintahuan siswa dalam belajar matematika masih kurang, dan fleksibel dalam pembelajaran matematika yang meliputi mencari ide-ide secara matematis masih kurang. Bahwa tingkat rasa percaya diri, keingintahuan, gigih dan ulet, berfikir fleksibel dan cara berfikir dalam pembelajaran matematika yang biasanya disebut disposisi matematis masih rendah. Selain itu, proses pembelajaran menggunakan metode ceramah sehingga siswa merasa jenuh dan kurang termotivasi untuk belajar.

Hal ini mengakibatkan prestasi belajar dan pengetahuan peserta didik menjadi rendah untuk mata pelajaran matematika. Selain itu, di lihat dari hasil ulangan harian matematika dengan jumlah kesuluruhan 25 siswa hanya mencapai rata-rata 66,2 dan belum mencapai nilai yaitu 68 .

Kondisi siswa seperti diatas jika dibiarkan saja akan mengakibatkan siswa semakin kesulitan dalam mempelajari dan memahami materi matematika lebih lanjut. Disposisi matematis merupakan faktor yang utama untuk kesuksesan belajar setiap siswa sehingga, tingkat disposisi matematis harus ditingkatkan. Dengan demikian perlu adanya model pembelajaran yang cocok agar proses pembelajaran dapat berjalan dengan baik sehingga dapat meningkatkan disposisi matematis dan prestasi belajar siswa. Salah satu model pembelajaran yang diharapkan dapat meningkatkan disposisi matematis dan prestasi belajar yaitu model pembelajaran kooperatif tipe AIR (Auditory, Intellectualy, Repetiton).

Shoimin (2014:29) menjelaskan bahwa AIR merupakan sigkatan dari auditory, intellectual dan repetition. Belajar bermodal auditory yaitu belajar mengutamakan berbicara dan mendengarkan. Sementara menurut Erman Suherman (dalam Shoimin, 2008: 29) auditory bermakna bahwa belajar haruslah melalui mendengarkan, menyimak, berbicara, prestasi, argumentasi mengemukakan pendapat, dan menganggapi. Sehingga dari Auditory rasa percaya diri siswa dan keingintauan siswa, gigih dan ulet dalam pembelajaran matematika akan meningkat sehingga dengan sehubungan hal tersebut prestasi belajar siswa akan meningkat. Kemudian dengan Intelletualy juga bermakna belajar haruslah menggunakan kemampuan berfikir, haruslah dengan kontrasi pikiran dan berlatih mengunakanya melalui bernalar, menyelidiki, mengindentifikasi, menemukan, mencipta, mengonstruksi, memecahkan masalah, dan menerapkan.

Hal ini dapat meningkatkan berfikir fleksibel dan cara berfikir dalam pembelajaran matematika dapat meningkat. Selain pembelajaran matematika prestasi belajar siswa juga akan meningkat. Menurut Suherman (dalam Shoimin, 2008: 29) repetition merupakan 
pengulangan, dengan tujuan memperdalam dan memperluas pemahaman siswa yang perlu dilatih melalui pengerjaan soal, pemberian tugas, dan kuis. Pengulangan dalam kegiatan pembelajaran dimaksudkan agar pemahaman siswa lebih mendalam, disertai pemberian soal dalam bentuk tugas latihan atau kuis. Hal ini juga akan meningkatkan prestasi belajar siswa. Dengan kelebihan metode AIR tersebut diharapkan akan meningkatkan disposisi matematis siswa dan prestasi belajar siswa akan meningkat.

Berdasarkan permasalahan di atas mendorong untuk melakukan perbaikan terhadap disposisi matematis dan prestasi belajar matematika kelas 3 SD N Awu-Awu mengenai materi matematika dengan melakukan penelitian tindakan kelas dengan judul "Peningkatan Disposisi Matematis dan Prestasi Belajar Matematika Melalui Pembelajaran Kooperatif tipe AIR (Auditory, Intellectualy, Repetiton) siswa kelas 3 SD N Awu-Awu".

\section{METODE PENELITIAN}

Penelitian ini dilaksanakan di SD Negeri Awu-Awu Purworejo pada kelas III di semester ganjil (semester satu) tahun pelajaran 2019/2020, pada waktu pelajaran Matematika. Subjek dalam penelitian ini adalah peserta didik kelas III SD Negeri AwuAwu Purworejo yang berjumlah 25, terdiri dari 18 laki-laki dan 7 perempuan. Sumber data penelitian yaitu disposisi matematis dan prestasi belajar siswa kelas III SD tersebut. Penelitian ini merupakan penelitian tindakan kelas yang mengacu pada desain penelitian yang dikemukakan oleh Kemiis dan Mc Taggart dalam (Kunandar, 2013: 42). Penelitian ini dilaksanakan dalam dua siklus yang setiap siklus terdiri dari dua kali pertemuan. Pertemuan ini terdiri dari perencanaan, pelaksanaan, pengamatan, dan refleksi. Di setiap tindakan, peneliti menerapkan model pembelajaran AIR dengan tujuan untuk meningkatkan disposisi matematis dan prestasi belajar matematika khususnya pada mata pelajaran matematika materi dolanan lambang bilangan.

\section{HASIL DAN PEMBAHASAN}

Penelitian tindakan kelas yang dilakukan di SD Awu-Awu menunjukkan bahwa pembelajaran Matematika materi lambang bilangan dengan penerapan model pembelajaran AIR dapat meningkatkan disposisi matematis dan prestasi belajar siswa kelas III. Terbukti dengan data pengamatan/observasi Berdasarkan pengamatan pada siklus I pertemuan I jumlah skor disposisi matematis siswa adalah 128 dengan presentase sebesar 46,54\%. Siswa yang sudah memenuhi indikator disposisi matematis sebanyak 12 siswa dengan presentase sebesar $0.48 \%$. Sedangkan pada pertemuan II jumlah skor yang didapatkan 140 siswa dengan presentase sebesar 50,90\%. Siswa yang sudah memenuhi indikator disposisi matematis sebanyak 14 siswa dengan presentase sebanyak 0,56\%. Rata-rata presentase disposisi matematis siswa pada siklus I sebesar 48,72\%.

Di awal pertemuan masih banyak siswa yang pasif, saat guru bertanya pada siswa kebanyakan dari mereka diam. Jika menjawab, siswa memberikan jawaban secara bersamaan dengan teman yang lain. Saat disuruh mengerjakan LKS masih banyak siswa yang mengandalkan temannya. Saat akan dilaksanakan diskusi kelompok, sebagian siswa tidak langsung duduk dalam kelompok-kelompok yang telah ditentukan. Hanya beberapa siswa yang berani bertanya tentang materi yang belum dipahami.

Kekurangan pada siklus I diperbaiki pada siklus II agar disposisi matematis siswa dapat meningkat. Pada siklus II LKS antar kelompok yang berdekatan dibuat berbeda agar tidak ada siswa yang meminta jawaban pada kelompok lain. Selain itu peneliti juga memberikan hadiah kepada siswa yang mau bertanya dan mau mempresentasikan jawaban 
di depan kelas. Diharapakan dengan adanya motivasi tersebut, siswa akan lebih aktif mengikuti setiap tahap pembelajaran.

Pada siklus II siswa sudah mulai terbiasa dengan pembelajaran AIR. Jadi mereka sudah lebih siap untuk melaksanakan pembelajaran. Sebagian dari mereka sudah duduk berkelompok tanpa harus disuruh oleh guru. Saat guru bertanya di awal pembelajaran siswa tidak hanya diam. Siswa menjawab pertanyaan dengan baik walaupun bersama-sama dan ketika guru meminta salah satu siswa untuk mengulang jawaban beberapa siswa berani mengangkat tangan mereka. Disposisi matematis pada siklus II dinilai lebih baik dari siklus I. interaksi siswa dengan anggota kelompoknya berjalan dengan baik. Peningkatan yang terlihat dari hasil pengamatan sesuai lembar observasi antara lain ditunjukkan pada disposisi dengan mental dan emosi yang ditunjukkan dari keterlibatan dalam diskusi dan mengikuti pembelajaran dengan baik. Peningkatkan lain terjadi pada disposisi matematis siswa yang ditunjukkan dengan bertanya kepada guru, menjawab pertanyaan yang diajukan oleh guru. Siswa perlu diberikan motivasi atau arahan yang lebih sehingga apabila kehiatan kelompok kembali dilaksanakan siswa dapat berperan lebih aktif. Disamping itu adanya motivasi dengan memberikan hadiah kepada siswa yang membuat siswa semakin semangat belajar.

Hasil observasi pada siklus II pertemuan I jumlah skor disposisi matematis siswa adalah 166 dengan presentase 60,36\%. Siswa yang sudah memenuhi indikator disposisi matematis sebanyak 16 siswa dengan presentase sebesar 0,64\%. Sedangkan pada pertemuan II jumlah skor yang didapatkan adalah 174 dengan presentase sebesar 63,27\%. Siswa yang sudah memenuhi indikator disposisi matematis sebanyak 18 siswa dengan presentase $0.72 \%$. Rata-rata presentase disposisi matematis siswa pada siklus II sebesar $61,815 \%$ yang berarti telah mencapai indikator keberhasilan yang ditetapkan. Dari pengamatan pada siklus I dan siklus II, dapat diketahui bahwa ada peningkatan disposisi matematis siswa ke arah yang lebih baik setelah diterapkan pembelajaran kooperatif tipe AIR. Dimana presentase disposisi matematis siswa pada siklus I dan siklus II mengalami peningkatkan. terjadi peningkatan prestasi belajar Matematika dari sebelum dilakukan tindakan sampai ke siklus II; Rata-rata siswa pada awal sebesar 66,2 meningkat menjadi 69,04 pada siklus I dan meningkat lagi menjadi 87,68. Sejalan dengan kenaikan rata-rata kelas ketuntasan klasikal kelas pun meningkat dari 56\% sebelum tindakan menjadi $68 \%$ pada siklus I dan meningkat lagi menjadi $84 \%$ pada siklus II.

Disposisi matematis siswa yang meningkat berdampak pada meningkatnya prestasi belajar matematika siswa yang dilihat dari kenaikan rata-rata kelas dan ketuntasan klasikal kelas. Rata-rata prestasi belajar matematika siswa sudah mencapai 87,68 dengan jumlah siswa yang tuntas adalah sebanyak 21 siswa atau sebesar 84\%. Terlihat adanya peningkatan pada siklus I dari aspek disposisi matematis yang mencapai 48,72\% pada siklus I meningkat menjadi $61,815 \%$ pada siklus II. Rata-rata kelas pada siklus I yang semula $69,04 \%$ menjadi $87,68 \%$ pada siklus II. Serta ketuntasan klasikal mencapai $68 \%$ pada siklus I meningkat menjadi $84 \%$ pada siklus II. Sehingga dapat dikatakan bahwa penelitian selama siklus I dan siklus II menunjukkan adanya peningkatan disposisi matematis siswa dan prestasi belajar matematika dengan pembelajaran kooperatif tipe AIR.

\section{SIMPULAN}

Berdasarkan hasil penelitian dan pembahasan dapat diambil simpulan bahwa, pembelajaran kooperatif tipe AIR dapat meningkatkan disposisi matematis siswa kelas III SD Negeri Awu-Awu tahun ajaran 2019/2020. Dapat dilihat dari dari presentase lembar observasi disposisi matematis siswa pada siklus I siswa yang sudah memenuhi indikator sebanyak 14 dengan presentase $0,52 \%$ dan meningkat pada siklus II menjadi $0.68 \%$. 
Pembelajaran kooperatif tipe AIR dapat meningkatkan prestasi belajar matematika siswa kelas III SD Negeri Awu-Awu tahun ajaran 2019/2020. Jumlah siswa yang mencapai KKM sebanyak 17 siswa pada siklus I dan meningkat menjadi 21 siswa pada siklus II.

\section{DAFTAR PUSTAKA}

Arikunto, Suharsimi, et al. 2017. Penelitian Tindakan Kelas. Jakarta: Bumi Aksara

Djamarah, Syaiful Bahri. 2012. Prestasi Belajar dan Kompetensi Guru. Surabaya: Usaha Nasional.

Kunandar. 2014. Penilaian Autentik. Depok: Rajagrafindo Persada. Pendidikan Nasional Nomor 22 Tahun 2006

Djamarah, Syaiful Bahri. 2012. Prestasi Belajar dan Kompetensi Guru. Surabaya: Usaha Nasional.

Nawaliyah, Qomariyah.N. (2015). Penerapan Pembelajaran Dengan Pendekatan AIR Pada Materi Sifat-Sifat Bangun dan Hubungan Antara Bangun Di Kelas V SD. Jurnal Model Pembelajaran Air.Vol 3, No 2.Hal 7.

Retnowati, D. (2013). Upaya Meningkatkan Pemahaman Konsep dan Disposisi Matematis Menggunakan Model Pembelajaran Treffinger.Jurnal Disposisi Matematis. Hal 2

Shaifuddin, M. et al. (2016).Penerapan Model Pembelajaran Kooperatif Tipe (Auditory, Intellectually, Repetition) Untuk Meningkatkan Kemampuan Operasi Hitung Campuran Bilangan Bulat Pada Siswa Sekolah Dasar.Jurnal Model Pembelajaran AIR.

Shoimin, Aris. 2014. 68 Model Pembelajaran Inovatif Kurikulum 2013. Yogyakarta: ArRuzz Media.

Sormin.Azizah.M. (2017).Peningkatan Kemampuan Komunikasi dan Disposisi Matematis Siswa Melalui Pembelajaran Kooperatif Tipe Jigsaw di SMP Muhammadiyah Kota Padangsidimpuan.Jurnal Disposisi Matematis.Vol 2, No 1. Hal 54-55 